\title{
First Contact with Possible Futures
}

\author{
Michael P. Oman-Reagan ${ }^{1}$ \\ Vanier Scholar, Department of Anthropology, Memorial University, St. John's, NL, Canada \\ Affiliated Researcher, University of Victoria, Victoria, BC, Canada
}

Please cite as:

Oman-Reagan, Michael P. 2018. "First Contact with Possible Futures." Speculative Anthropologies series, Theorizing the Contemporary, Cultural Anthropology website, December 18. https://culanth.org/fieldsights/1626first-contact-with-possible-futures

Speculation about the future has often been colonized by militarists, nationalists, capitalists, xenophobes, and other elitists and bigots. But there have also always been better ways to imagine and encounter possible futures of life on Earth and in the space between stars. Consider Lou Cornum's (2015) figure of the space NDN who, "in a long tradition of NDN interstellar exploration," uses "technologies such as creation stories and ceremony as her means of travel." As Cornum (2015) observes, Indigenous futurisms demonstrate that "many of the ideas deemed strange or new-fangled in Western sci-fi come naturally to the space NDN.” Afrofuturisms, along with disability, refugee, queer, and other futures, use creative speculation and resistance imagination to unnaturalize oppression. A better world is possible.

What good is any anthropology that doesn't imagine better lives and futures, and then work to make them real? Billions of us imagine futures without capitalism's artificial scarcity; without borders, prisons, and cages; without military empires; without land theft, resource extraction, and colonialism; without hierarchies, power inequalities, and the abuses they enable; without precarious labor or bullshit jobs (see Graeber 2018). The futures imagined in the course of everyday life suggest an opening for vibrant, compelling, and relevant speculative ethnography in solidarity with those who dream. I use speculative ethnography to mean any creative engagement with possible futures crafted using imaginative anthropological approaches toward the aim of building just and ethical relations across spatial and temporal scales. Yes, any.

Consider ethnographic ethics in Carolyn Ives Gilman’s “Twenty Planets” science-fiction series, in which exoethnologists and xenologists work within a galactic information-exchange economy — trading information about ways of doing, thinking, and being. The first book of the series, Halfway Human (Gilman 1998), is the story of a society where children have no gender until they are "matriculated" and receive one (or not). Those not gendered become so-called blands, an enslaved group whose labor enables their gendered oppressors' privileged lives. Halfway Human is both about a genderless character, Tedla, and an alien culture researcher who meets Tedla after their escape from slavery. The researcher learns how oppression is structured on Tedla's home world through Tedla's testimony. Halfway Human is speculative ethnography of oppression, resistance, witness, and solidarity.

1 omanreagan@mun.ca 
Interstellar speculative ethnography appears again in Gilman's (2015) novel Dark Orbit. On a corporatefunded scientific expedition to a distant world, the ship's exoethnologist debates ethics and methods with her crewmates. She serves a dual role, observing conflicting academic disciplines and scientific approaches among the crew and the culture of the planet below. The exoethnologist is joined by another social scientist, a so-called sensualist who studies methods of sensing by immersing herself in them. She is a specialist in varieties of perception and affect, devoted to learning new techniques. Dark Orbit is, in part, a speculative ethnography of how techniques and knowledge are acquired or appropriated from other cultures, how those cultures are compensated or not, and how the techniques may be used or misused. Like Ursula K. Le Guin's fiction, Gilman's writing addresses anthropological issues while exploring contact between seemingly alien species. These species are often members of Earth's interstellar human diaspora who have been living on different worlds for so long they have become alien to each other.

Read as speculative ethnography, this kind of fiction can communicate urgent anthropological issues better than journal articles. Speculative ethnography is built from the same stuff as scientific ethnographic work, while also bringing seemingly distant possibilities into the time and space of ongoing history. In Time and the Other, Johannes Fabian (1983) describes epistemological problems arising from a split between the experience of fieldwork and the practices of producing anthropological discourse. To overcome these problems, we need to acknowledge that the people we study live in the same time we do — to establish relations of coevalness, as Fabian puts it—and to allow that contemporaneity to penetrate anthropological discourse, putting aside the fear that our writing might be "disqualified as poetry, fiction, or political propaganda" (Fabian 1983, 109). Hope can disrupt the feeling that change is impossible. And what is hope, if not establishing coeval relations with the future?

Consider anthropological accounts of anarchisms, utopias, sexualities, and political economies in Octavia E. Butler's Xenogenesis series, Iain M. Banks' Culture books, Le Guin's Hainish worlds, and Samuel R. Delany's haunting and refracted spaces of intimacy. N. K. Jemisin (2016), Cherie Dimaline (2017), Nnedi Okorafor (forthcoming), Nalo Hopkinson (2000), and others often do anthropology better than the dead white men on the syllabus. For Marlene Barr (1993, 10), feminist science fiction is "a stop sign in relation to patriarchy and a go-ahead signal for women." Donna Haraway (2013) has described science fiction as the "stem cells" of her multispecies work. Walidah Imarisha $(2015,3)$ teaches that "whenever we try to envision a world without war, without violence, without prisons, without capitalism, we are engaging in speculative fiction."

Today, a socially networked media pandemonium celebrates technocapitalist progress while imprisoning humanity in centuries-old structural inequalities. This scene can make alternative futures appear impossible. However, the future-as-possibility must exist if we want to break the foundations of a seemingly inescapable, unrelenting, fascist now. As Le Guin $(2004,220)$ wrote, "we cannot demand that anyone try to attain justice and freedom who has not had a chance to imagine them as attainable."

The poetic and political hope of social justice imagination can help us believe in the existence of the future again by imagining it as attainable. Speculative ethnography shares and extends that into future encounters with changing worlds, ecosystems, cultures, and lives. To borrow Le Guin's $(2004,219)$ description of imagination, I hope more anthropologists will embrace being "dangerous to those who profit from the way things are because it 
has the power to show that the way things are is not permanent, not universal, not necessary." The exoethnologist

in Gilman's Dark Orbit is also an expert on the ethics and practice of first contact with alien life. Speculative ethnography can teach us to imagine justice and freedom as attainable in all our first contacts with today's emerging realities and with the possible, hopefully more just, futures yet to come.

\section{Acknowledgements}

This research was supported by the Social Sciences and Humanities Research Council of Canada.

\section{References}

Barr, Marleen S. 1993. Lost in Space: Probing Feminist Science Fiction and Beyond. Chapel Hill: University of North Carolina Press.

Cornum, Lou. 2015. “The Space NDN’s Star Map.” New Inquiry, January 26.

Dimaline, Cherie. 2017. The Marrow Thieves. Toronto: Dancing Cat Books.

Fabian, Johannes. 1983. Time and the Other: How Anthropology Makes Its Object. New York: Columbia University Press.

Gilman, Carolyn Ives. 1998. Halfway Human. New York: Avon.

2015. Dark Orbit. New York: Tor.

Graeber, David. 2018. Bullshit Jobs: A Theory. New York: Simon and Schuster.

Haraway, Donna J. 2013. “SF: Science Fiction, Speculative Fabulation, String Figures, So Far." Ada, no. 3.

Hopkinson, Nalo. 2000. Midnight Robber. New York: Warner Books.

Imarisha, Walidah. 2015. "Introduction.” In Octavia's Brood: Science Fiction Stories from Social Justice Movements, edited by adrienne maree brown and Walidah Imarisha, 3-6. Oakland, Calif.: AK Press.

Jemisin, N. K. 2016. The Fifth Season. London: Orbit.

Le Guin, Ursula K. 2004. “A War without End.” In The Wave in the Mind: Talks and Essays on the Writer, the Reader, and the Imagination, 211-20. Boston: Shambhala.

Okorafor, Nnedi. Forthcoming. Binti: The Complete Trilogy. New York: Penguin Random House. 